.....Iraqi National Journal of Earth Sciences Vol. 18, No. 1, pp. 9 - 26, 2018.....

\title{
Geobotanical Study of Some Areas South-Western Mosul by using Remote Sensing and ASD Dataset
}

\author{
Rayan Gh. Thannoun \\ Remote Sensing Center \\ University of Mosul
}

\author{
Sabah H. Ali \\ Remote Sensing Center \\ University of Mosul
}

Nameq A. Al-Munaem

Remote Sensing Center

University of Mosul

( Received 26/8/2013 ，Accepted 7/11/2013)

\begin{abstract}
To investigate the health of vegetation and soil purity in some areas south- western Mosul city, multi spectral remote sensing and Analytical Spectral Device (ASD) field spectrometer were used. Landsat ETM+ image was used to identify tonal spectral anomaly after correct it spectrally by using ENVI's FLAASH method. A combination of False color composite image (FCC) based on the spectral characteristics of vegetation and soils was selected. This combination consists of (Band7-Red, Band4-Green, Band1-Blue) and also used to express the subtle grey tones as color variations and then some of anomalous reflectivity zones were extracted. Field spectral measurements were applied to determine the spectral reflectance anomaly of vegetation and soils. The spectral measurements of the samples were made in spectral analysis laboratory at (Remote Sensing Center- Mosul University) on a number of samples with a full-range of ASD spectrometer (i. e. $350 \eta \mathrm{m}$ to $2500 \eta \mathrm{m}$ ), both on and off the anomalous spectral zones in order to compare the spectral changes between them. The results confirmed to the existing these reflectance zones by determination an increase in the reflectance at the chlorophyll absorption as well as a shift in the position of the red edge. The results also have indicated that the anomalous relationship between the occurrence of hydrocarbon seepages and anomaly reflectance zones. In this context, the migration of hydrocarbons has a predominantly structural control, related to the listric fault and accompanying fractures.
\end{abstract}

Keywords: Geobotany, ASD Field Spectrometer, Image Processing and Tectonics. 


\section{دراسة جيويوتونية لبعض مناطق جنوب غرب الموصل باستخدام معطيات التحس النائي وجهاز التحليل الطيفي}

\author{
نامق عبد المنعم \\ مركز التحسس النائي \\ جامعة الموصل
}

\author{
صباح حسين علي \\ مركز التحسس النائي

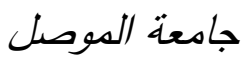

\author{
ريان غازي ذنون \\ مركز التحسس النائي

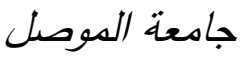

\section{الملخص}

استخدمت معطيات التحس النائي متعددة الاطياف وجهاز التحليل الطيفي في التحري عن حالة النبات

الصحية ومدى نقاء الترب من الملوثات لبعض المناطق في جنوب غرب الموصل. بغية تحديد انطقه التباين

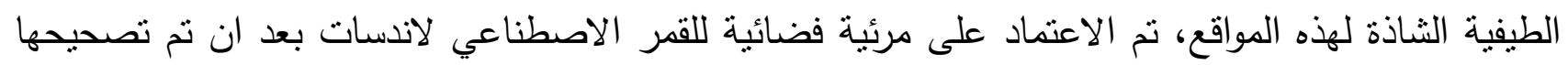
طيفيا من خلال طريقة تصحيح الغلاف الجوي (FLAASH method) وتركيبها بالدمج الملون الكاذب للحزم الطيفية (741) اعتمادا على الخصائص الطيفية للنباتات والترب وذلك لاستخدامها في عرض التغيرات المفاجئة في الدكانة بشكل تباين لوني ومن ثم استخراج انطقة التباينات الطيفية. تم اجراء التحاليل والقياسات

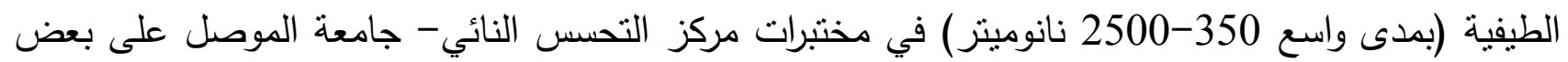
نماذج من النباتات والترب التي تم جمعها من مواقع ضمن منطقة الدراسة والتي اظهرت تباينا شاذا في في في

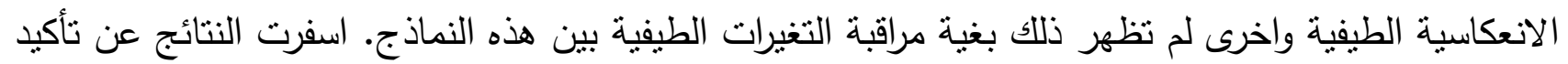
وجود هذه التباينات الثاذة في الانعكاسية الطيفية من خلال تحديد زيادة في الانعكاسية ضمن مناطق امتصاص لهردية الكلوروفيل فضلا عن وجود ازاحة واضحة في الحد الطيفي الاحمر ـ كما بينت الدراسة وجود علاقة موقعية بين الانطقة الطيفية الثناذة ومواقع النضوحات الهايدروكاربونية نتيجة هجرتها اذ تتحكم فيها عوامل نركيبية متعلقة بوجود الصدع الليستيري وما برافقه من تكسرات في البنية الجيولوجية للمنطقة. الكلمات الدالة: جيوبونوني، جهاز التحليل الطيفي الحقلي، معالجة رقمية، تكتونيك. 


\section{INTRODUCTION}

Approximately, 70 percent of the Earth's land surface is covered with vegetation, furthermore, vegetation provides a basic foundation for all living beings and it is one of the most important components of the ecosystem. Knowledge about variations and alterations in vegetation provide valuable insight into the geologic, climatic, etc.. of an area (Shafri, et al., 2005).The environmental influences in the soil are reflected also to the vegetation. These influences show in the satellite images as a tonal anomalies and subtle changes in spectral content which are used as important indications in remote sensing for detect the altered areas that are related to contaminated zones, oil and gas seepage etc. (Almida - Filho et al, 1999); (Shi, 2010); (Zhang et al., 2010). Geobotany has been defined as the study of plants as related specifically to their geologic environment as well as it used to define geologic patterns in the landscape and it defines also as an integration of the physical and biological processes of interest to earth science (Rose et al., 1979; Raines and Canney,1980) in (Rencz, 1999). This work tests the hypothesis that chemical and biological changes in vegetation and soils in some areas south western Mosul city are related to the hydrocarbon seepage. Corrected Landsat7 enhanced thematic mapper plus (ETM+) imagery was used to map anomalous spectral zones associated with these seepages. Field spectral measurements were applied to determine the spectral reflectance anomaly of vegetation and soils samples in both on and off the anomalous spectral zones. The results and the applied technique of this study are very important in the practical applications related to the field of primary oil survey as well as for understanding the impact of local tectonic factor on the geological structures.

\section{STUDY AREA}

Two areas were selected in this research (Fig. 1). The first is located in the west of Mosul city, specifically on the footslope zone of Shaikh- Ibrahim anticline with geographic position between (Lat. 36 $20^{\prime} 30 " \mathrm{~N}$ and $36^{\circ} 12^{\prime} 30$ "N) and

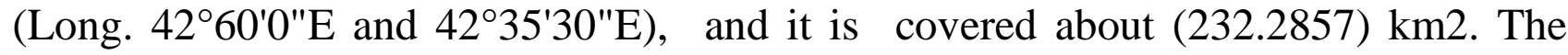
second is located in the south eastern of Mosul city on the footslope zone of Kirkuk anticline with geographic position between (Lat. 35 50 $0^{\prime} \mathrm{N}$ and $35^{\circ} 42^{\prime} 0$ "N) and (Long. $44^{\circ} 6^{\prime} 30^{\prime \prime} \mathrm{E}$ and $43^{\circ} 56^{\prime} 0^{\prime \prime} \mathrm{E}$ ), and it is covered about (392.8) $\mathrm{km} 2$. The second area (i.e. Kirkuk) were studied only by false color processing because of the difficulty 
of access to it, as well as it is oil productive areas. Generally, footslope zone of the both two areas represented a zone of quaternary deposits or pediment surface surrounds the major exposed folds (i.e. Shaikh- Ibrahim and Kirkuk). Typically, this surface is gently to rolling topography and composed of unconsolidated Quaternary sediments. Geological setting of the studied area includes several folds with their stratigraphic units are exposed on the surface. In the first area, Shaikh- Ibrahim anticline represent the major, asymmetrical and cylindrical anticline. The fold axis of this structure trends towards north west - south east. The lithological units are exposed in these structures include Euphrates, Fatha and Injana formations (GeosurvIraq, 1995). In the second area, Kirkuk anticline is the asymmetrical and cylindrical fold, with fold axis towards north west - south east. The lithological units are exposed in this structure include Kirkuk groups (Oligocene groups), Euphrates, Fatha, Injana, Mukdadiyah and Bai- Hassan formations (Geosurv- Iraq, 1993). Area under investigation has a semi-arid climate with average annual rainy under $(245 \mathrm{~mm})$ and mean annual temperatures around $\left(24-26 \mathrm{C}^{0}\right)$.

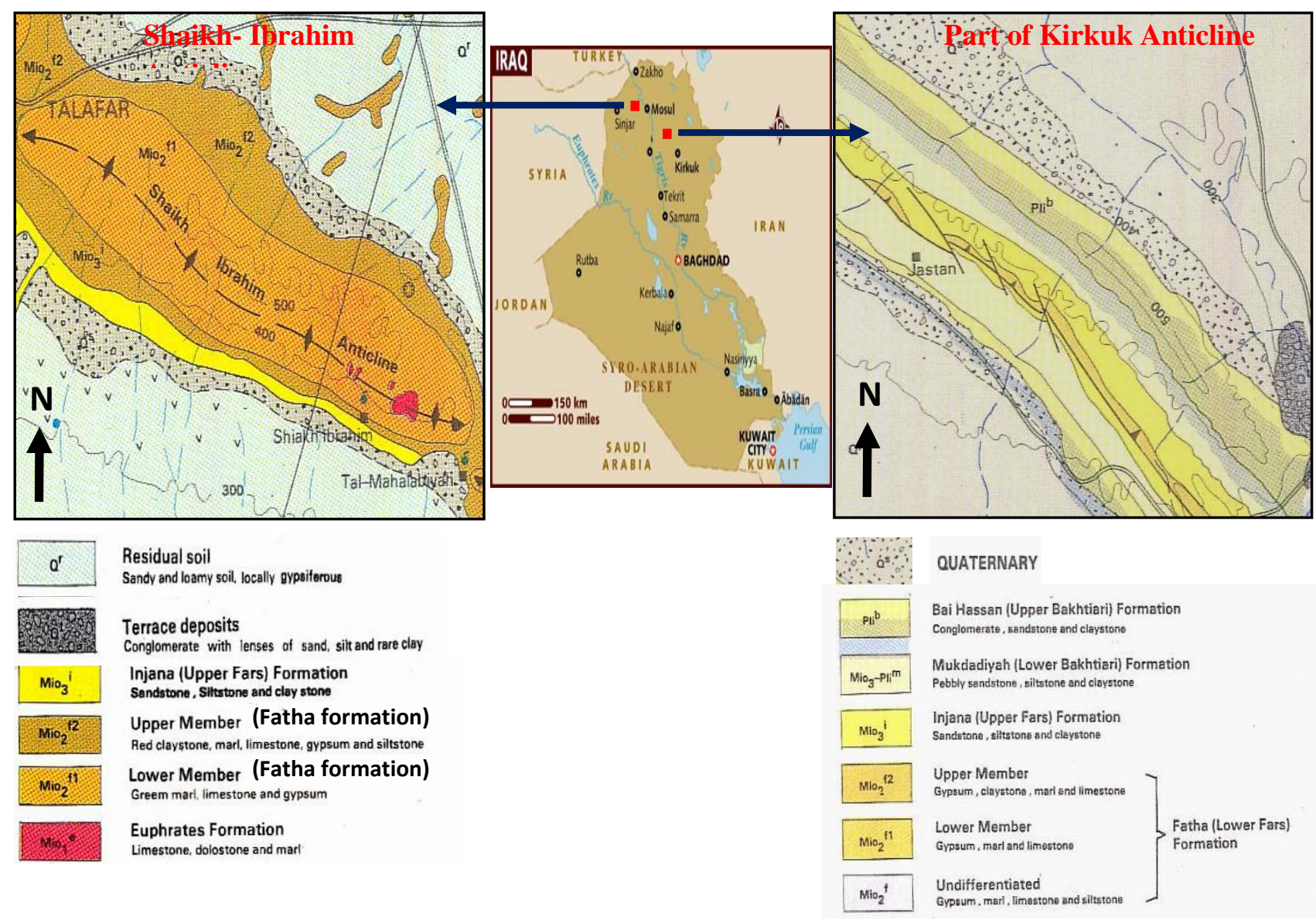

Fig. 1: Geographic location and Geologic Setting of the Study Area Geosurv - Iraq,1993,1995 


\section{Research Methodology}

The methodology followed by in this study consist of six steps of procedures:

1-Preparation the images and selected optimum bands after it corrected (geometrically and spectrally)

2- Determine the anomalous spectral zones in soil and vegetation by composing three selected bands of Landsat imagery

3- Field work including geologic, soil and planet survey, sample collection and GPS interpolation to all zones which are revealed spectral anomaly in the images.

4- Spectral curve measurement of planet and soil by laboratory work with ASD field spectrometer analysis.

5- Validation of previous analysis to estimate planet chlorophyll health and soil purity.

6- Investigate the potential causal relationship between identified anomalous spectral zones and the hydrocarbon seepages.

The later sections summarily describe the detail of each steps which is taken to achieve this objective.

\section{Vegetation and Soil Spectral in Remote Sensing}

Generally, vegetation health is affected by some factors like industrial pollution, salinity, ...etc. Remote sensing techniques be used to determine the changes in vegetation. Healthy vegetation in the visible zone (i.e. from 0.4-0.7 $\mu \mathrm{m}$ ) characterized by absorption features by the plant chlorophyll. Whereas, in the near infrared and shortwave infrared characterized by four absorption features (Fig. 2). High reflectance of vegetation in (NIR) is also ranged from $(0.8$ and $1.1 \mu \mathrm{m})$ and depending on the internal structure leaf. In order to determine the vegetation stress, the researcher must be notice the three spectral criteria (Noomen, 2007; Yang, et al., 2000, freeman, 2003) 


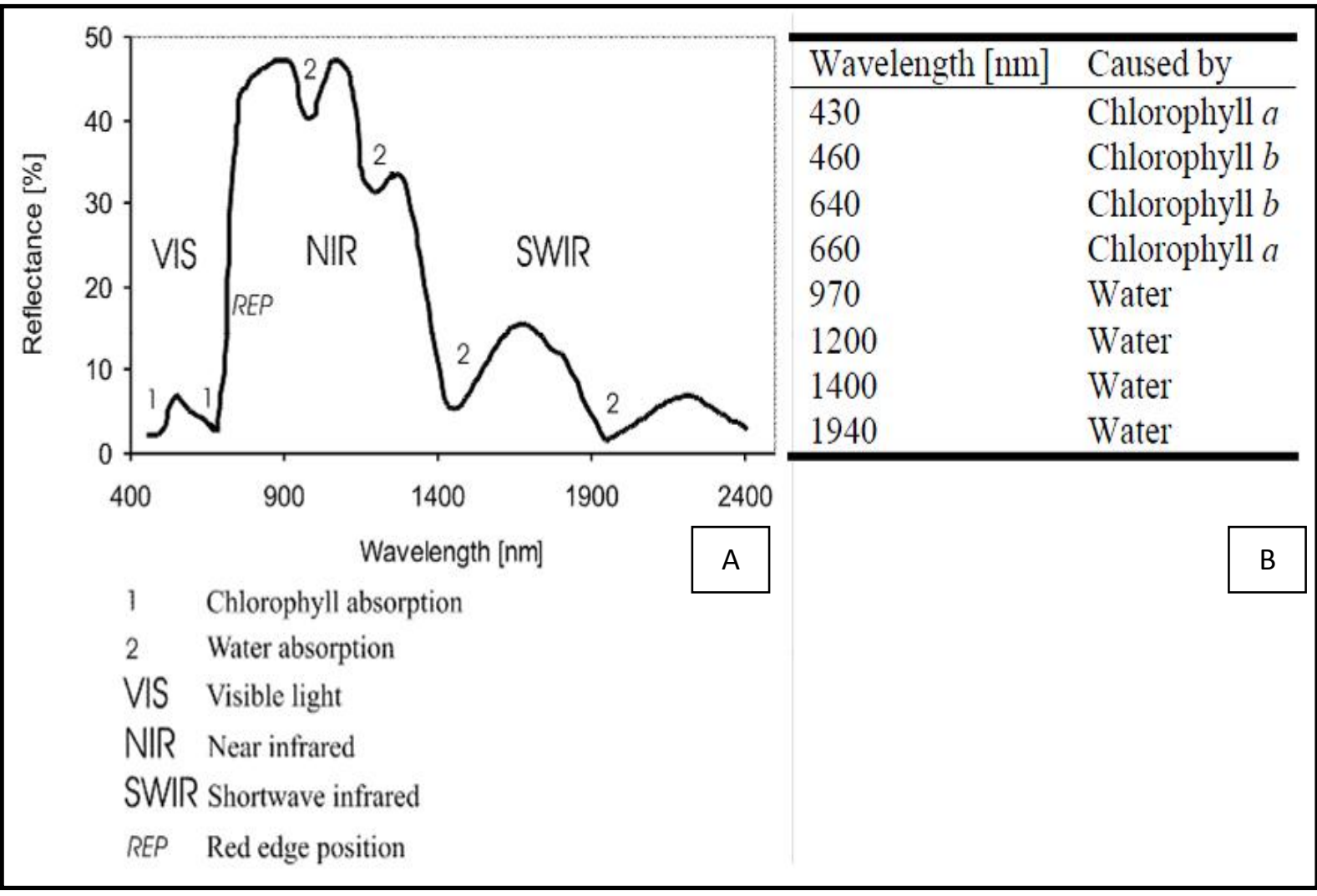

Fig. 2: A. Typical vegetation reflectance curve with indication of major absorption. B. Major absorption features in vegetation reflectance. (Noomen, 2007).

1- A decrease in the NIR reflectance due to structural damage.

2- An increase in the reflectance at the chlorophyll absorption maximum due to decreased leaf chlorophyll.

3- A shift in the position of the red edge towards shorter or longer wavelengths, this shift occurs when there is hydrocarbon seepage.

Soil is a mixture of inorganic mineral particles and organic matters of varying size and composition. Remote sensing can provide the identification, inventory, and mapping of soils, especially when surface soils are not covered with dense vegetation. Spectrally, the reflectivity of soils increases at increasing wavelengths. The intense absorption of radiant energy by soil moisture creates a series of minima, centered approximately at (1.4, 1.9 and $2.7 \mu \mathrm{m}$ ), (Fig. 3), (Profeti, 2005).

High metal concentrations in the soil cause the changes of its standard spectral curve and abnormal size, shape, and spectral reflectance characteristics of vegetation 
(Sabins, 1999). A relationship between spectral reflectance properties of plants and the content of their soils could form the basis for remote sensing to determine the important exploration criteria. For example, the presence of hydrocarbons in soils stimulates the activity of hydrocarbon-oxidizing bacteria, which decreases oxygen content of the soil whilst increasing its contents of carbon dioxide and organic acids, then these changes affect $\mathrm{pH}$ and Eh of soil, which in turn affect the solubility of elements that are plant nutrients and consequently their availability to vegetation (Schumacher, 1996).

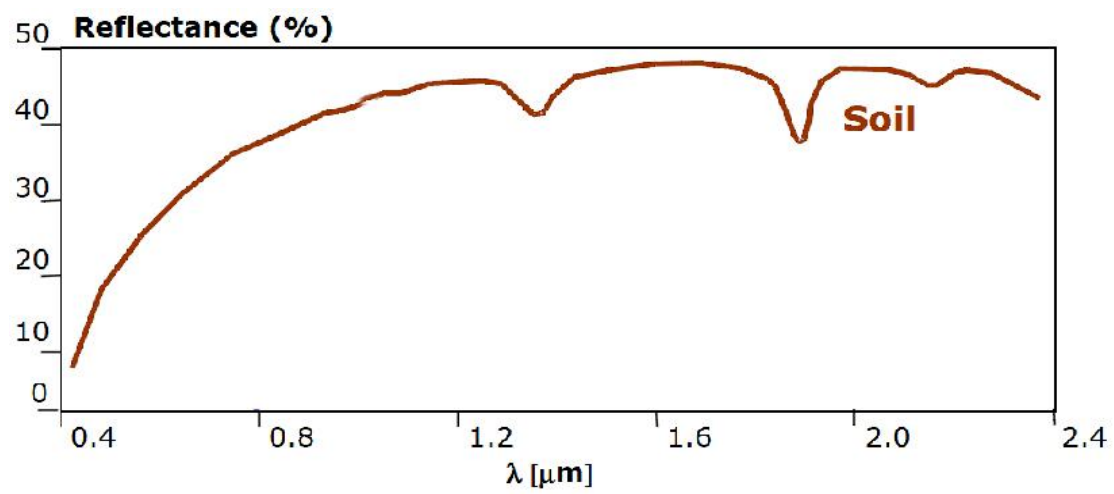

Fig. 3: Spectral Reflectivity Curve of Soil (Modified from Profeti, 2005).

\section{Image processing}

Image processing of Landsat ETM+ was used to extract the anomaly zones in soil and vegetation (which are associated with hydrocarbon seepage) as well as to help understand the tectonic factor on this zones. The steps of this processing are discussed below:

1- Pre-processing: Landsat image requires preprocessing prior to the analyses. Geometric corrections are performed to eliminate the systematic and nonsystematic distortions related with the physical and geometric conditions of the scanning devices. Preprocessing is used also to correct the spectral distortion of the image by using ENVI's FLAASH method, or Fast Line-of-Sight Atmospheric Analysis of Spectral Hypercube, then the data was corrected spectrally.

2- False color composites: A composite is an image which combines different wavelengths into the same image. Combinations of Landsat $\mathrm{ETM}^{+}$bands can be useful to provide overviews of landscape and geological materials due to their characteristics reflectance and absorption in different wavelengths (Binh, 2003). However, the spectral information stored in the individual bands can be integrated by combining them into a color composite. In this context, the spectral information is combined by displaying each individual band in one of the three 
primary colors ( Red, Green and Blue). Every combination of bands used to create a color composite image is called a False Color Composite (FCC). In this study, the red color is assigned to the middle-infrared band (Band 7), the green color to the near-infrared band (Band 4) and the blue color to the blue visible band (Band 1). The health vegetation will appear greenish (Fig. 4).

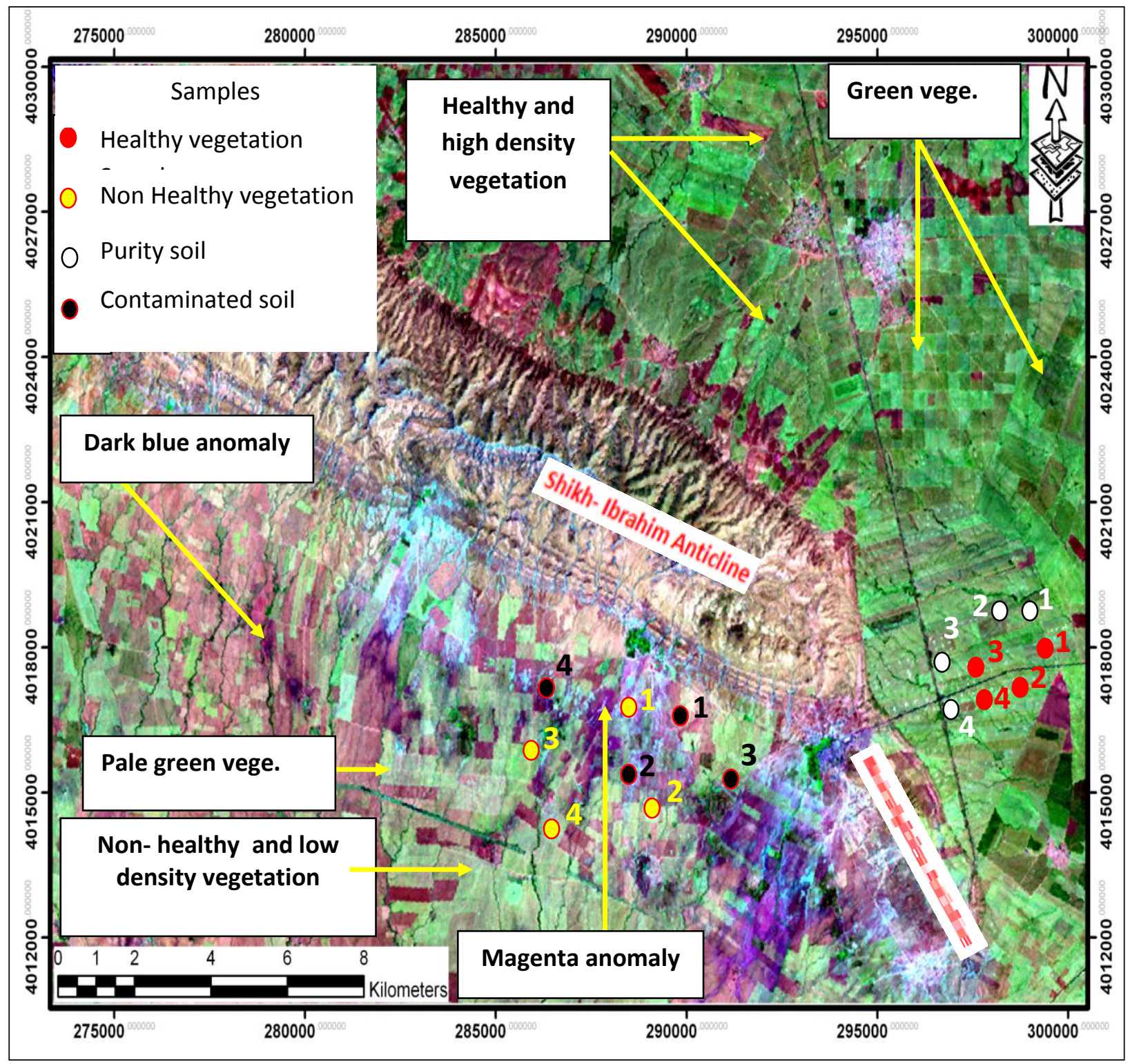

Fig. 4: False Color Composite Image of (Shaikh - Ibrahim anticline) West of Mosul City (R: Band-7, G: Band-4, B: Band-1). 
As shown in the (Fig. 4), the spectral properties of common surface materials at the studied area including vegetation, exposed rocks and regolith materials (soils) that can be resolved in the visible and near infrared zone of the electromagnetic spectrum scale when using Landsat ETM images. However, The FCC image were interpreted to identify areas which have subtle changes in spectral. These areas, called anomalous spectral zones, were plotted on a FCC image. In vegetation and soils, two major types of these zones are noticed:

1- According to the band settings and RGB color composite in this study, healthy vegetation appears as green color, but towards the southern part of Shaikh-Ibrahim anticline, the vegetation appears as pale green color (Fig. 4). In this context, the density of vegetation (i.e., vegetation per unit) is varied between the north eastern and south western parts of this anticline. The high density of vegetation is located towards the north eastern part of Shaikh- Ibrahim anticline. Meanwhile, it is clear that most areas which have low density of vegetation located at the south western part of this anticline (Fig. 4).

2-In the non-vegetated areas which are covered by soils, two types of local anomalous spectral zone are noticed. The first, magenta/ and or dark blue color is the most frequent anomalous spectral zones at the south western part of Shaikh- Ibrahim anticline. The pattern of these zones revealed line feature whose parts align straight. The second, pale magenta color which is covered some areas at the south western parts of this anticline with random distribution.

\section{FIELD WORK}

Field work took place over the March of 2013, during which the following objectives were accomplished:

1- Determination the ground truth of anomalous spectral zones (in the field) by GPS auto- tracking techniques.

2-Collect samples of vegetation and soil from areas showed anomalous spectral reflectivity and collect the same samples from other regions appeared normal in reflectivity (i.e., did not show an anomaly in the spectral reflectivity) to monitor the difference of the spectral changes for both samples. Twenty samples of vegetation and soils were gathered from the area under investigation. The vegetation was sampled from selected area as shown on (Fig. 4) with yellow and red circles. These samples represent (rangeland's grasses ), (Hordeum Vulgare- Barley type 
plant) and (Triticum aeslivum-wheat type plants) (Fig. 5), which are prevalent in the study area and occupies large areas (especially in areas that did not show variations in the spectral reflectivity on the Landsat image). The samples were collected also from the wheat plant in areas showed a variation in reflectivity and other areas did not show it (Fig.5). The soil was sampled from selected area which are shown on (Fig. 4) with white and black circles. Most soil samples are collected at a depth of 20 centimeters through a metal core $(10 \mathrm{~cm}$ in diameter), which is lifted parts of the soil and keep it from collapsing (Fig.5) also, several soil samples have been sampled from areas characterized by the existence anomaly in the spectral reflectivity and the other did not show that.

\section{ASD Spectrometer Laboratory Analysis}

Using the ASD Spectrometer in spectral analysis laboratory at Remote Sensing Center- Mosul University. Spectroscopy analysis was performed on a number of samples with a full-range of AS dspectrometer (i. e., $400 \eta \mu$ to $500 \eta \mu$ ). The objective of this analysis is to determine the subtle and shifting in the spectral curve of samples by comparison between them, and then determine the anomalous samples. In order to extract the spectral changes, eight samples were selected and displayed in the current study. Four of these samples were collected from anomalous zones like pale green in (Fig. 4), and compared (spectrally) with the other four samples (with the same classes) which are collected from un anomalous zones like green vegetation in (Fig. 4). (Fig. 6) display eight samples of vegetation were analyzed spectrally. Sample (1) represents natural planet- healthy (rangeland's grasses type) (Fig. 6-A). Sample (2) represents natural planet- stress (rangeland's grasses type) (Fig. 6-B). Sample (3) includes healthy planet (barley type) (Fig. 6-C), whereas sample (4) includes natural planet- stress (barley type) (Fig. 6-D). The samples (5 and 6) have been taken from wheat plant (both healthy and stress) (Fig. 6 - E and 6 - F). Also (Fig. 7) shows four samples of soils. Samples (1 and 2) ( clay loam type), are represents soil which has been collected from agriculture field on the south eastern part of Shaikh- Ibrahim anticline as white circles on (Fig. 4). Whereas, Samples (3 and 4) (also clay loam types), were collected from the south western part as black circles on (Fig. 4). 
Gebotanical Study of Some Areas South-Western Mosul by using

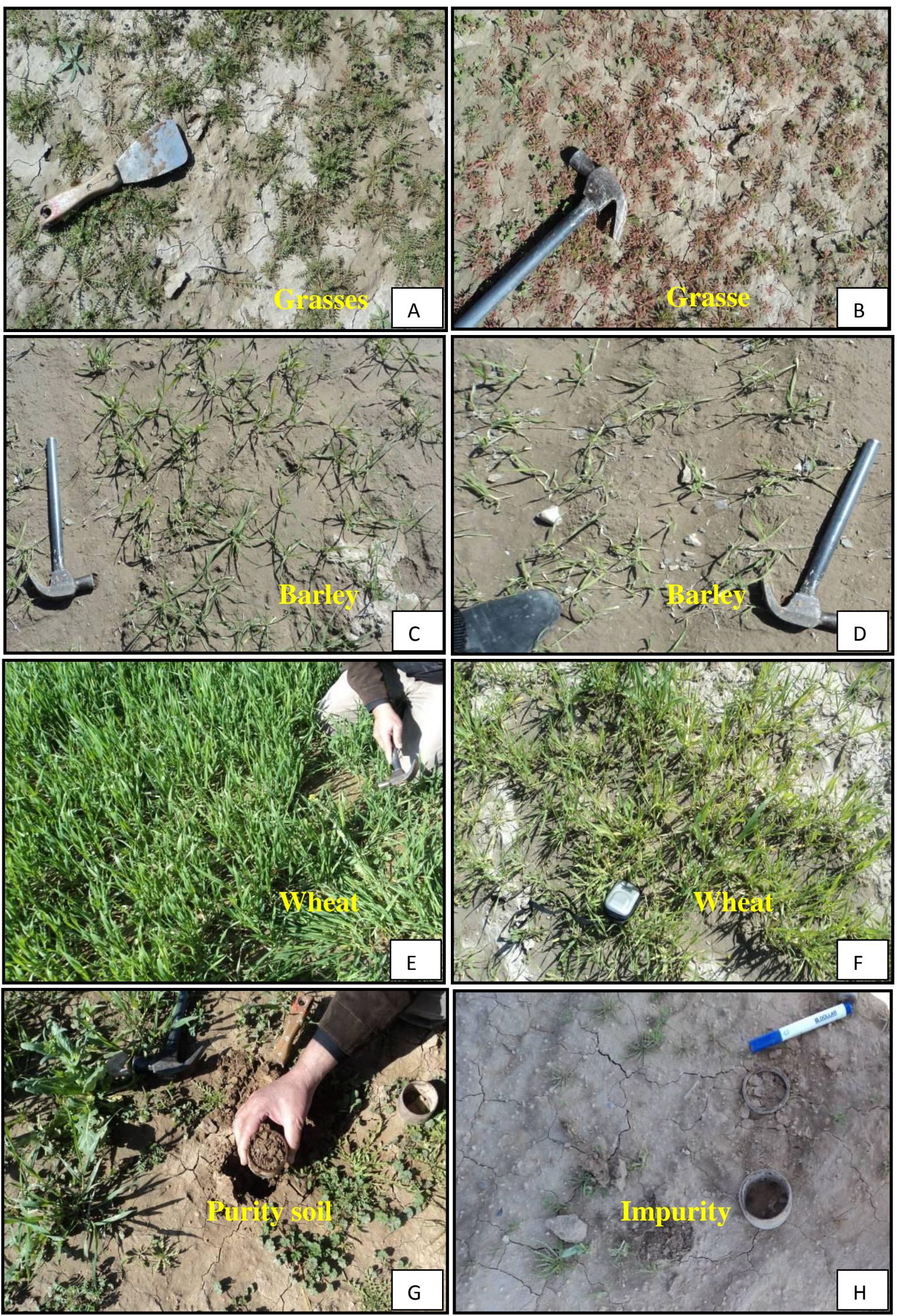

Fig. 5: Photographs Showing Collected Samples (both Vegetation and Soils).in Shaikh Ibrahim Anticline . 


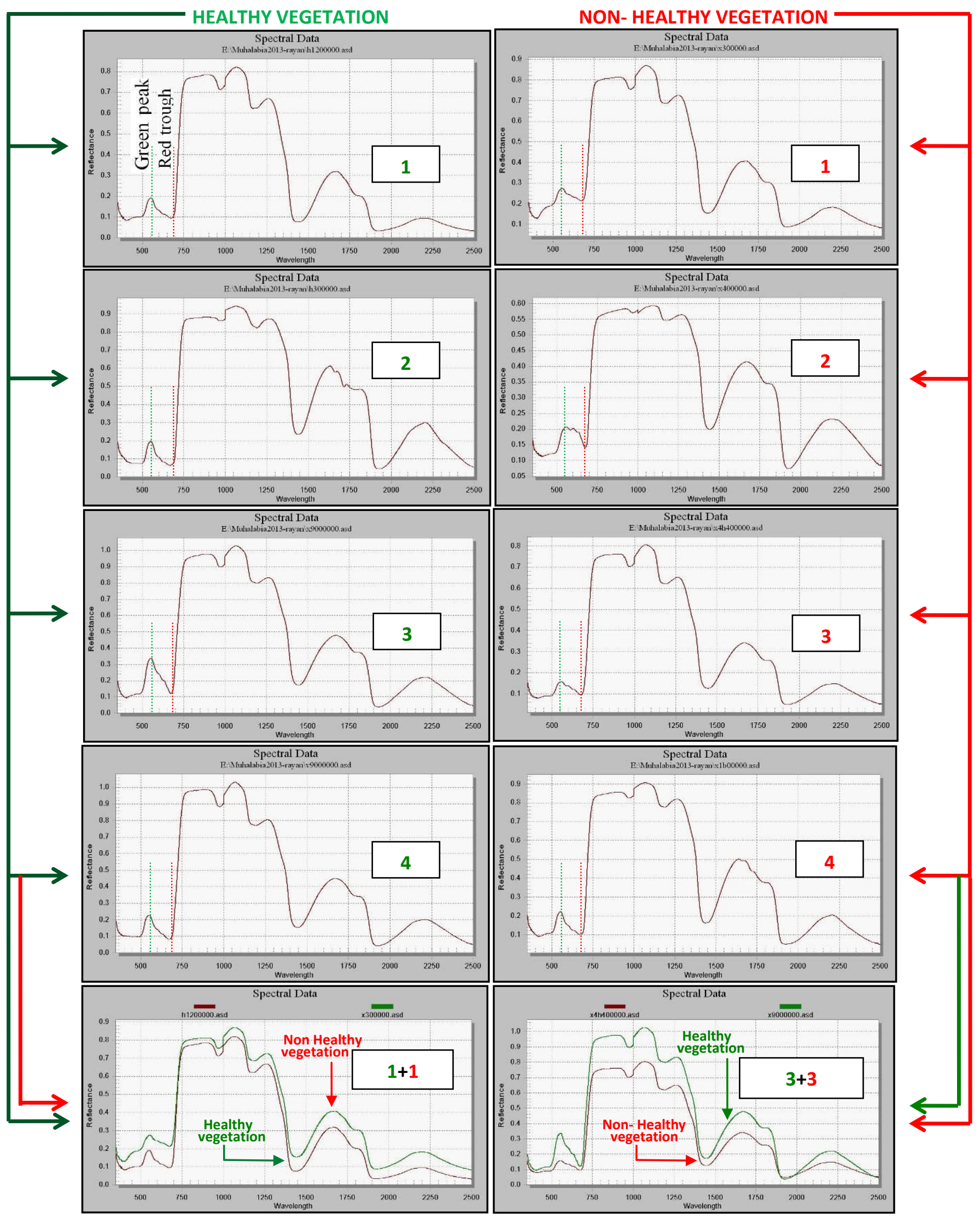

Fig. 6: Measured Reflectance Curves of Vegetation Samples. 

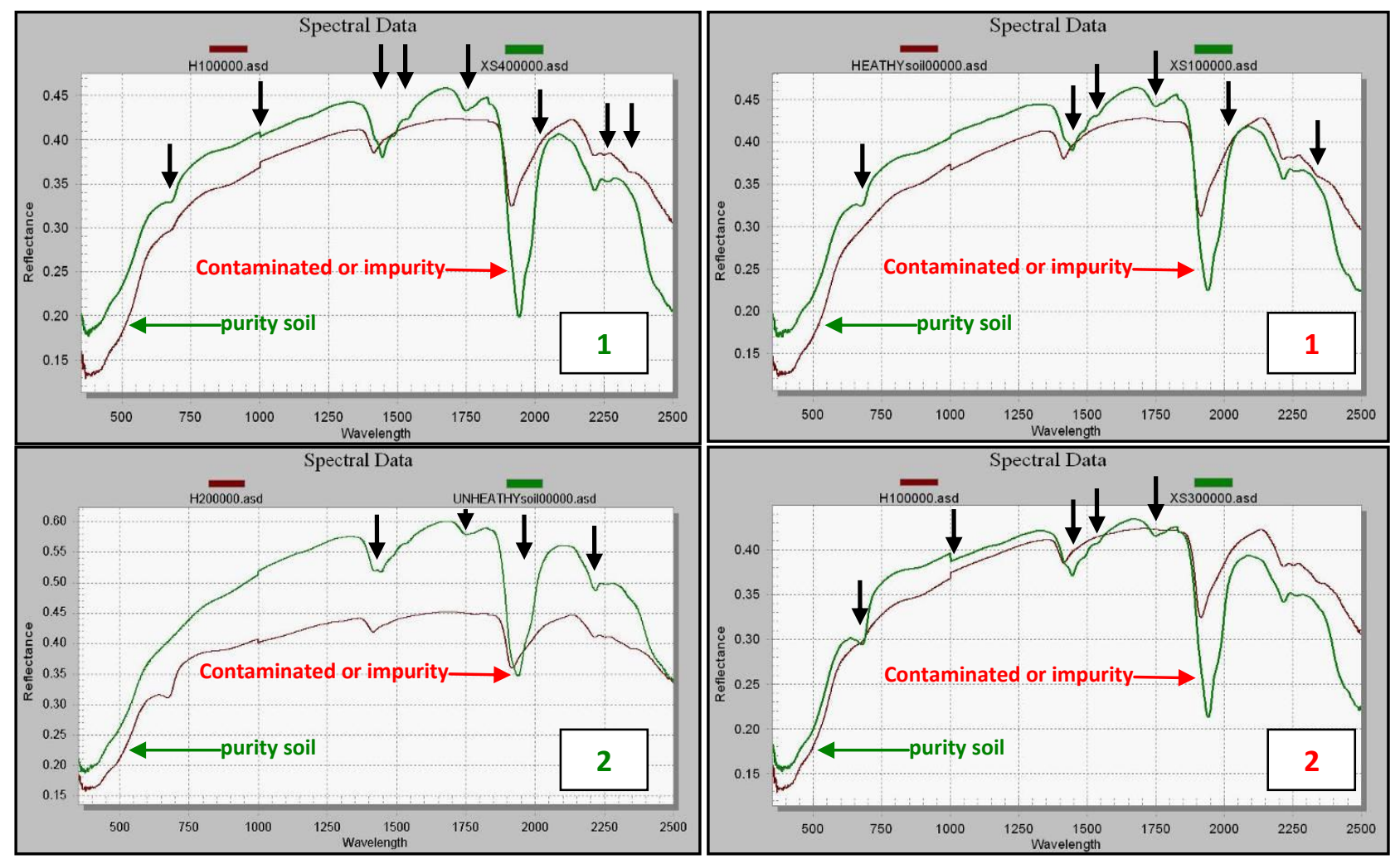

Fig. 7: Measured Reflectance Curves of Soils Samples.

As shown in (Fig. 6 and Fig. 7), the components and contents in vegetation and soils have characteristic and significant spectral responses, so the spectra will change when there is variation, as the following:

1- In vegetation, spectral curve of anomalous (or stressed) vegetation takes two forms. The first, shift position of green peak (at $0.56 \mathrm{~nm}$ ), and red trough (at $0.67 \mathrm{~nm}$ ).

2- This shift be towards shorter wavelength, in this context, the shift of red trough is larger compared with the green peak. Red and green shift be clear by merging spectral curve of both healthy and non healthy vegetation as shown in (Fig. 6). The presence of this spectral curve variations between two samples (i.e., healthy and non-healthy vegetation) may be attributed to presence of hydrocarbon seepages. In this context, (Al- Banaa, 2012) was pointed to the existence of two types of hydrocarbon seepages in Shaikh- Ibrahim anticline (microseepage and macroseepage). The second, the increasing spectral reflectance. as shown in (Fig. 6), the spectral curve intensity of non healthy vegetation increasing about 
(30\%) compared with the spectral intensity of healthy vegetation. This increase due to decreased leaf chlorophyll and this was observed in the field.

3- In soil, (Fig. 7) shows the different in two spectral curves by merging two samples of both on and off the spectral anomaly zones. The following variations has been noticed:

A: From (Fig. 7), It can be seen that the reflectance of soils in the anomalous zones is higher (in intensity) than ones outside of the anomalous zones. This indicates that there exists alteration in soils from these zones. According to the (Wang and Ding, 2000), the increase of ferrous-iron content and the decrease of ferric-iron content in the altered soil (due to the presence of hydrocarbon seepages) may cause the increase of reflectance.

B: Spectral curves of contaminated soils exhibit obvious absorption feature as shown in (Fig. 7) with black arrows. A very strong absorption feature ranged from (1850 $\eta \mu-2050 \eta \mu)$. The occurrence of this absorption location has been linked to hydrocarbon seepage by many authors (Yang et al., 2000), (Yang et al., 1998; Cloutis, 1989; Horig et al., 2001; Hunt, 1979; Ellis et al., 2001; McCoy et al., 2001; Buckingham and Sommer, 1983) in (freeman, 2003). According to that these seepages are changes the chemical composition of the soil at the studied area, and then the resultant new mineral has been created.

\section{Relationship Between Local Tectonic Setting and Spectral Variation of both: Vegetation and Soil}

Based on false color Landsat image as well as ASD field spectrometer analysis, spectral curve variation in vegetation and soils have been detected in the south western foot slope zone of Shaikh - Ibrahim anticline. Occurrence of this variation is most likely due to the presence of hydrocarbon seepages. In this context, (Al- Banaa, 2012) confirmed existence of hydrocarbon seepages evidence through his study of Shaikh-Ibrahim anticline and supported that by geochemical analysis of selected rocks samples and also by applying some of advance image processing methods like principal components and spectral ratioing analysis. In this study a model for hydrocarbon microseepage in Shaikh - Ibrahim anticline was developed (Fig. 8). This model shows hydrocarbon migration from the subsurface through networks of fractures and faults, consequently, it is impact on the vegetation and soils. These fractures and faults were formed due to compressional forces during the Alpine 
orogeny. According to the (Al- Azzawi, 2002) most of the folds of the Foreland Belt of Iraq are geographically, orientationally and genetically related to the listric faults. This conclusion can be interpreted of the presence of anomalous spectral zones on the one side of this fold (i.e. the south western part toward footslope). According to several studies related to tectonic setting in Iraq, all of them indicate that the compressive forces are recently still active in the foreland zone of Iraq, Consequently, this activation contribute to migrate of hydrocarbons from their respective reservoirs to the surface. (Al- Banaa, 2012) reported that the hydrocarbon in some parts of the southern limb of Shaikh- Ibrahim anticline actively seep and natural bitumen deposits are widespread at these parts. In this context, geomorphological transport processes might have played a major role by transferring these contaminated material to the downslopes (i.e., footslope) and then it also influenced on the vegetation and soils.

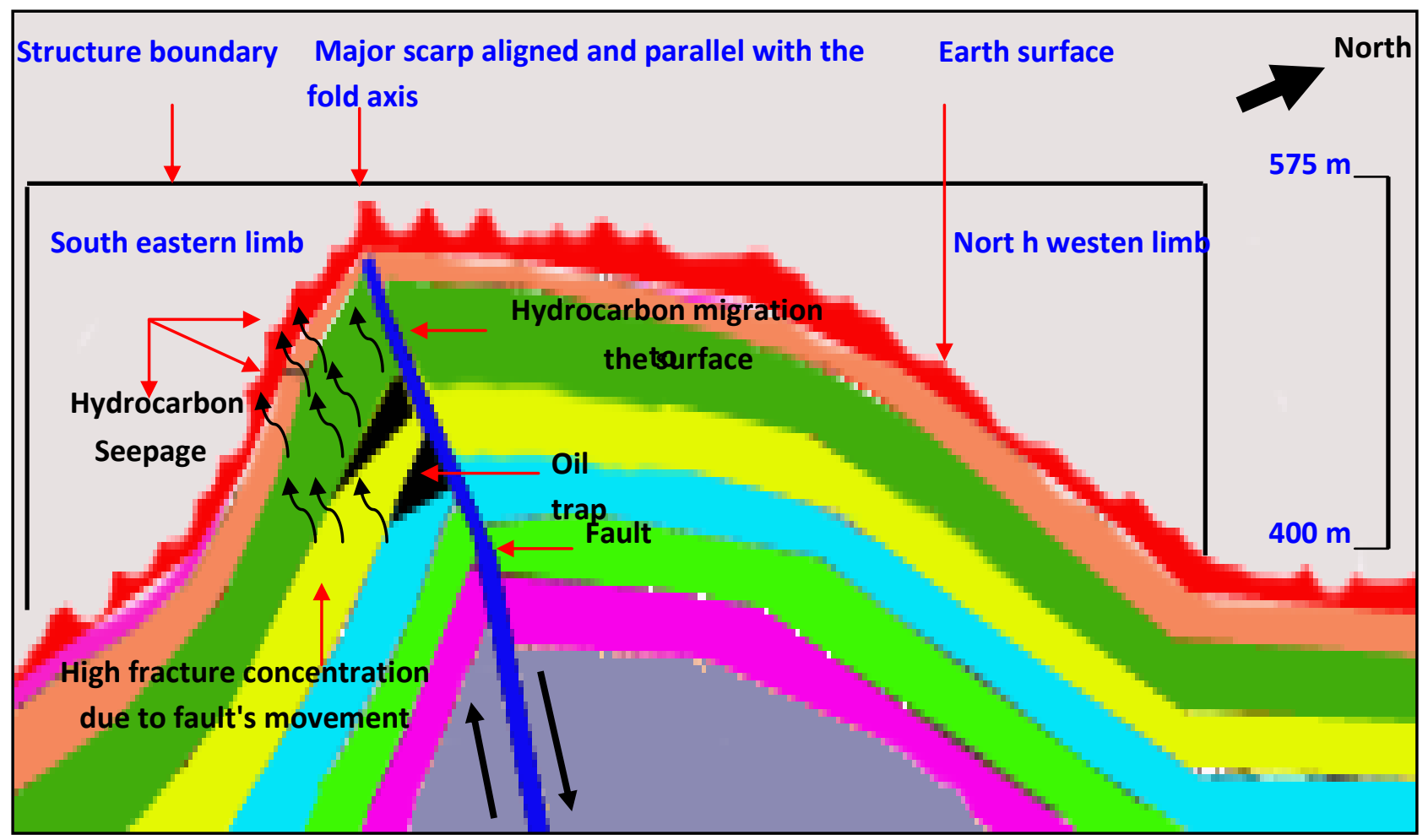

Fig. 8: Generalized Model of Hydrocarbon Seepage in Shaikh - Ibrahim Anticline. 


\section{Test the Efficiency of the False Color Composite Processing in Determining Vegetation Health}

In order to test the efficiency of false color composite processing as well as the selected spectral bands of Landsat satellite in determining the health of vegetation and purity of soils, a part of Kirkuk anticline was selected. Many of studies like (Perry and Kruse, 2010), (Al-Banaa, 2012), were pointed to the existence of hydrocarbon seepages in this anticline. According to the band settings and RGB color composite which are used in this study, some of anomalous spectral zones can be detected which are reflect hydrocarbon seepage impact on the vegetation and soils. These zones are plotted on the (FCC image) (Fig. 9). However, hydrocarbon seepages in this fold caused by fault which is extends along Kirkuk anticline (parallel to its axis), (Fig. 1).

\section{CONCLUSION}

This study demonstrates successful application of remote sensing and ASD field spectrometer to identify the health of vegetation and purity of soil. Remote sensing methods employed spectrally and geometrically corrected image which are enhanced by false color composite processing in order to determine the subtle changes in spectral color (i. e., anomalous spectral zones). Spectral curves have been extracted based on laboratory spectroscopy taken from samples which are collected within field work of the studied area. This study suggests that the both adopted image processing of FLAASH correction and false color composite are applicable for this type of studies. In this context, comparing spectral response of vegetation and soils with false color image will confirm the presence of anomalous zones. This study showed the relationship between the occurrence of hydrocarbon seepages and anomalous zones. It is possible to identify that the migration of hydrocarbons has a predominantly structural control, related to the listric fault and accompanying fractures. 


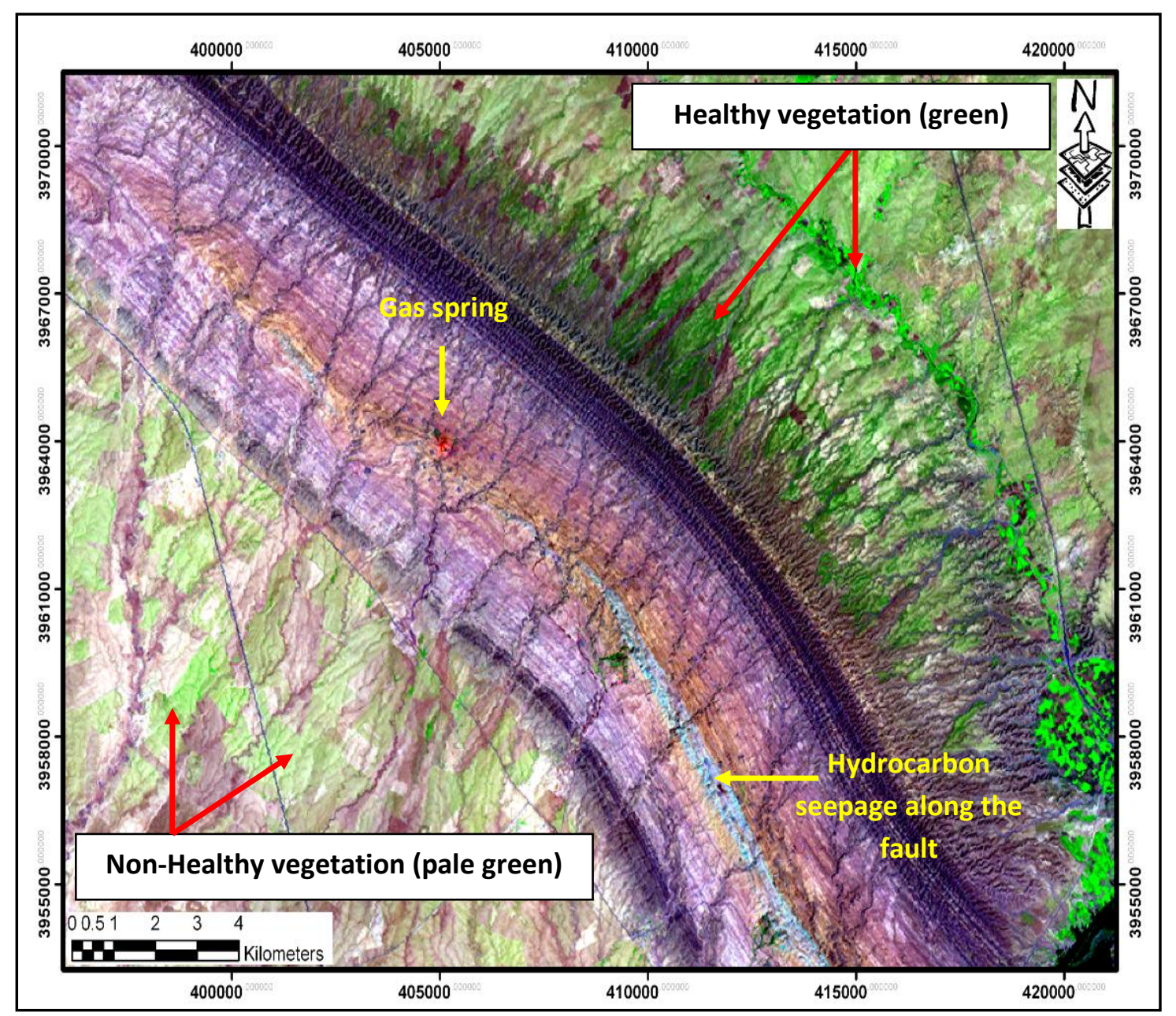

Fig. 9: False Color Composite (Part of Kirkuk Anticline) (R: Band-7, G: Band-4, B: Band-1).

\section{REFERENCES}

Al-Azzawi, N. K. B., 2003. The Structural Development of Folds Shape in the Foreland Belt of Iraq, and its Tectonic Implications, Unpublished Ph. D. thesis, Mosul Uuniversity, Iraq, 203p.

Al-Banaa, R. Gh. 2012. Structural Control Evaluation of Hydrocarbon Seepages in Northern Iraq Using Remote Sensing Techniques, Ph.D.Thesis, Mosul University, Iraq, $222 \mathrm{p}$.

Binh, N. D., 2003. Integrating Remotely Sensed and Geophysical Data for Geological Study in Tamduong - Nw Vietnam, Msc. Thesis, Ghent university, Belgium, 92p. Freeman, H., 2003. Evaluation of the Use of Hyperspectral Imagery for Identification 
of Microseeps Near Santa Barbara, California. Project 2 Report for Master of Science, University of West Virginia, $22 \mathrm{p}$.

Geosurv - Iraq, 1993. Geological Map of Kirkuk Quadrangle, Sheet Ni-38-2, 1: 250,000. State Establishment of Eurvey and Mining, Baghdad, Iraq.

Geosurv - Iraq, 1995. Geological Map of Al- Mosul quadrangle, Sheet Nj-38-13, 1: 250,000. State Establishment of Survey and Mining, Baghdad, Iraq.

Noomen, M. F., Skidmore, 2007. Hyperspectral Reflectance of Vegetation Affected by Underground Hydrocarbon Gas Seepage, Ph D Thesis, ITC, Netherlands, 151p.

Perry, S. 1. and Kruse, F. A., 2010. Evidence of Hydrocarbon Seepage Using Multispectral Satellite Imagery, Kurdistan, Iraq, AAPG International Convention and Exhibition, September 12-15, 2010, Alberta, Canada.

Profeti, G., 2005. Fundamentals of Remote Sensing Image Processing "Lecture Notes, $60 \mathrm{p}$.

Rencz, A.n. , 1999. Remote sensing for the Earth sciences, $3^{\text {rd }}$ edition. John Willey and Sons incop., United States, 672 p.

Sabins, F. F., 1999. Remote Sensing for Mineral Exploration, Ore Geology Reviews, Vol. 14, pp. 157 - 183.

Schumacher, D.,1996. Hydrocarbon-Induced Alteration of Soils and Sediments, AAPG Memoir 66, pp. 71 - 89.

Shafri, H. Z., Salleh, M. A. and Ghiyamat, A., 2006. Hyperspectral Remote Sensing of Vegetation Using Red Edge Position Techniques, American Journal of Applied Sciences Vol. 3, No. 6, pp. 1864 - 1871.

Shi, P., Fu B. and Ninomiya, Y., 2010. Mapping Hydrocarbon Seepage-Induced Anomalies in the Arid Region, West China Using Multispectral Remote Sensing, International Archives of the Photogrammetry, Remote Sensing and Spatial Information Science- Kyoto Japan. Volume XXXVIII, Part 8. pp. 442 - 447.

Yang, H., Van Der Meer, F. D., and Zhang, J., 2000. Aerospace Detection of Hydrocarbon-Induced Alteration, Handbook of Exploration Geochemistry, Vol. 7, pp. 233 - 245.

Zhang, G., Shen X., Zou L. and Shanlong L., 2010. Identifying Hydrocarbon Leakage Induced Anomalies Using Landsat-7 /ETM+ Data Processing Techniques in the West Slope of Songliao Basin, China. International Journal of Remote Sensingunder Press. http://www.a-a-r-.org/acrs/proceeding/ACRS2007/Papers/TS16.1.pdf 